УДК 334.021 .1

JEL J180, J190

ORCID ID 0000-0001-7174-7556

ORCID ID 0000-0002-4178-1662

DOI https://doi.org/10.17721/tppe.2021.42.9

Iryna Berezhna, Doctor of Economics, Professor, Fondo Bilateral para el Desarrollo en Transición Chile - Unión Europea, Santiago, Chile Olena Grishnova, Doctor of Economics, Professor, Taras Shevchenko National University of Kyiv, Ukraine Ekaterina Mikhurinskaia, Doctor of Economics, Professor, Fondo Bilateral para el Desarrollo en Transición Chile - Unión Europea, Santiago, Chile Artem Berezhnoy, Doctor of Economics, Supply chain manager, Hunland Impex BV, Netherlands

\title{
SPATIAL PLANNING AS THE BASIS FOR SPATIAL DEVELOPMENT, CONSOLIDATION OF EFFORTS AND SOLIDARITY OF THE UNITED EUROPE PART 1.
}

Considering that the goal of the spatial development of the European Union is to ensure the sustainable development of European regions, strengthen democratic structures at the regional and municipal levels and increase competitiveness, the usefulness of spatial planning is justified. This will allow improving the placement of productive forces, resettlement schemes, highlighting the areas of the most important natural objects, taking into account economic specialization, the level of development, the nature of the use of natural resources and economic potentials, etc. An integrated approach to spatial planning is proposed, which provides for identifying the features of the supporting frame, zoning the territory taking into account social, economic and environmental characteristics, and optimizing the territorial structure. This will create conditions for overcoming structural changes in the spatial development of the region related to the need to regulate land use processes, the integration of various regions (industries, companies), the development of single-industry towns and rural areas, the optimization of transport corridors, and the stabilization of the environmental background. Attention is paid to the harmonious mutual development of ecological and economic systems, which is provided by the design of the architecture of the supporting and ecological frames. At the same time, the results of studies on the level of anthropogenic and technogenic load, maximum permissible standards for the use of natural resources (water bodies, land resources, air, etc.), as well as, the presence of pathogenic zones, should be taken into account. The implementation of the proposed approach requires the consolidation of the efforts of territorial communities at different levels, based on the principles of cooperation, integration and unification, which will consider the general development trends and specific characteristics of the territories. The main result will be the strengthening of the commonwealth, strengthening the solidarity of the participating countries in achieving strategic guidelines for the balanced development of the European Union and effectively countering modern challenges.

Key words: spatial development; European Union; sustainable development, spatial planning, optimization of the territorial structure. 
The implementation of the social harmony strategy of the Council of Europe involves the spatial development methods and tools that can identify the regional characteristics of the participating countries, determine points of economic growth and take into account the challenges and risks of transformations of the world economy. At the same time, it should be borne in mind that spatial development processes are subject to the influence of globalization, a change in the geographical configuration of world centers of economic influence, an increase in demographic destruction, and the achievement of a critical level of anthropogenic and man-made impact, which determine the strategic goals of economic, environmental and social development of the regions.

Problem statement. This strengthens the need to deepen the scientific basis of spatial development in order to harmonize national and pan-European policies to improve the spatial organization of all member countries of the Council of Europe, to solve economic, social and environmental problems that go beyond the borders of individual states. Of particular importance are the theories of central places by V. Kristaller, the equilibrium model of the location of production by $\mathrm{A}$. Lesch, the concept of territorial-industrial complexes (N.N. Baransky, N.N. Kolossovsky), the theory of growth poles by F. Perrou, the theory of the axes of development by P. Potier, the theory of agglomerations by $\mathrm{P}$. Krugman and $\mathrm{P}$. Romer, the theory of cluster development by M. Porter, the theory of diffusion of innovations by T. Hegerstrand. These theories were developed in the works of such modern scientists as A.G. Grandberg, R.I.Schniper, O.S. Pchelintsev, M.I.Dolishny, L.I.Shevchuk and others.

Analysis of publications. Throughout the entire period of development of the theory of spatial economics, many scientific schools have been formed within the framework of classical political economics and modern theories of institutionalism.

Unresolved parts of the problem. Despite the existing variety of approaches to spatial planning, the scientific and applied foundations of the organization of economic and social space require further research, taking into account the development priorities of modern Europe as a form of unification of regions that are different in terms of resources and organization.

The purpose of the article. The purpose of the article is to study and synthesize classical approaches to the spatial development of a territory and modern theories of territorial planning, which will take into account regional characteristics, the commonality of social, economic and environmental priorities of the member states of the European Union.

Research methodology. The systematic approach and the concept of sustainable development of the territory were chosen as a general research methodology. To solve the set tasks, the methods of logical and system analysis, the method of associations and analogies, methods of statistical analysis were used.

Research results. The main goal of the spatial development of the European Union is to solve a three-pronged problem - ensuring the sustainable development of European regions, strengthening democratic structures at the regional and municipal levels and increasing competitiveness. This approach is reflected in the document "Fundamental 
Principles of Sustainable Spatial Development of the European Continent" (2002), according to which the following principles are approved:

- Ensuring territorial harmony through more balanced social and economic development of the regions and enhancing their competitiveness;

- promoting the development generated by urban functions and improving the relationship between the city and the village;

- creation of equal conditions of transport accessibility;

- development of access to information and knowledge;

- reducing environmental damage;

- Increasing and protecting natural resources and natural heritage;

- multiplying cultural heritage as a development factor;

- development of safe extraction of energy resources;

- promoting high-quality sustainable tourism;

- limiting the effects of natural disasters.

All the most important challenges of this period test the solidarity of the EU countries and the effectiveness of the adopted strategies, reflect the degree of balance between environmental, social and economic systems, increase migration mobility, which implies a spatial measurement of the processes caused by the economic crisis and pandemic. At the same time, it is necessary to take into account the spatial aspects of interregional, international and cross-border cooperation, the degree of stability of the economies of the EU member states to external influences, the nature of changes in the demographic sphere, in the field of industrial production, small and medium-sized businesses.

The long-term and balanced spatial development of the European Union should be based on close cooperation with the regional strategies and programs of the participating countries, capable of ensuring high competitiveness of the national economy, reducing the level of social and economic differentiation and ensuring equal access to transport and information infrastructure. This requires the consolidation of the efforts of territorial communities at different levels (local, regional, national, European), based on the principles of cooperation, integration and unification, which will allow taking into account general development trends and specific characteristics of the territories.

The development of interregional relations is a necessary condition for the deepening of specialization and integration of material production of the region, which involves the allocation of zones and territories either on certain grounds or relative to general problems. In our opinion, it is spatial planning that provides for taking into account the peculiarities of the territory (economic specialization, level of development, the nature of the use of natural resource and economic potentials, etc.), development of optimal location of productive forces, resettlement schemes, allocation of areas of the most important natural objects. As a result, it is possible to justify management decisions on spatial development in order to create conditions for the maximum effectiveness of the functioning of territorial economic systems, a favorable living environment, and balanced development of urban and rural territories. Thus, spatial planning allows for rational territorial organization of land use, multi-level integration (intercountry, interregional, intersectoral) within the framework of harmonizing social, economic and environmental priorities. This ensures the benefits of 
the optimal use of land, economic and natural resources, the formation of favorable zones for life, an increase in the level of accessibility of transport infrastructure and the polycentricity of the development of the region as the basis for spatial development.

Long ago, man sought to live in an organized space that not only helped to effectively carry out all types of human activities, but also formed a certain level of protection for people in a particular territory. However, economists quite recently began to study the organization of economic activities in a certain space within the framework of official science. Thus, classical economic theory focused more on the growth and stability of the economy, and not on the optimization of the placement of productive forces taking into account the spatial aspect. Moreover, according to the theses of the "anti-regionalists," in the spatial aspect there are many "non-economic" factors, the study of which goes beyond the framework of economic science. In this way, such scientific studies should be carried out combining geographical, sociological and other areas. ISARD (1956) drew the attention of economists to the spatial aspects of economic development and the need for their research, which is quite natural, since processes exist, both in time and in space.

In our opinion, in the history of research of the spatial aspects of economic development, several stages can be distinguished:

1.Attempts to determine the spatial order of economic phenomena in a homogeneous, at first glance, economic space by building spatial models of economic phenomena. This stage is marked by the development of the first models of space organization: models of agricultural zones, which are formed under the influence of the city (market center), described by THÜNEN (1826) in the book "Isolated State"; location models of industrial enterprises ROCHER (1854).

2.Developed by WEBER (1909) location theory or "Standort Theory," presented in the book "Theory of the location of industries". The role of the "location factor", based on which it was proposed to assess such economic benefits that can be obtained in economic activities depending on the place of economic activity, is justified.

3.The discovery in the early 1930s of the law of the mutual spatial location of settlements and highways by CHRISTALLER (1967) and LOSCH (1945). CHRISTALLER (1967) proposed the theory of "central places," according to which economic space is a hierarchical structure including cities and agglomerations. The regional aspect of theories of spatial development was first considered in the work of LOSCH (1945) "The economics of Location," which presents an equilibrium model of production placement. Economic space at the level of economic regions was considered, the size of which was determined by the level of economic relations.

4. The basic principles of theories of spatial development are proposed by ISARD (1956). In accordance with them, the economic space is determined by a system of industrial and inter-territorial ties. This approach was used by BARANSKY (1980), KOLOSOVSKY (2006) to develop the concept of territorial-industrial complexes, according to which the development of the economic region is associated with its specialization, and the placement of its corresponding enterprises, depending on the resources of the region.

5.The theory of multi-nuclearity has been developed by CHAUNCY, D. HARRIS and E. ULLMAN (1945). This theory justifies the development of the city not from one center, but 
around several clearly detectable centers. In some cases, these nuclei exist almost since the formation of the city, but in many cases they form during migration processes and progressive specialization. E. ULLMAN proposed the theory of movement, which allows the justification of the advantages of the spatial arrangement of production and its economic transport links.

6. The theory of "growth poles" of PERROUX (1950) is important in the development of spatial theories. F. PERROUX associated the spatial development with the concentration of resources in certain sectors of the economy, which caused the dominance of the range of economic entities in the economic space. The theory of "growth poles" has been developed in the directions of theories of spatial development related to the study of agglomeration effects (P. Krugman, P. Romer, J. Freedman), the organization of network structures (clusters) and development axes.

7.The theory of the supporting frame of the territory has been developed, which is used to increase the level of protection of people of a particular territory from unforeseen environmental influences. The essence of this theory is that such security depends primarily on the structure of the supporting frame of the territory, its level of development and stability. For the first time, the idea of the frame of the territory was expressed by $\mathrm{N}$. BARANSKY in 1946, and at the end of the twentieth century, LAPPO (1977) described the supporting frame as a combination of the main focuses of economic, political and cultural life and the main lines connecting them. The special role of the frame in the territorial structure of the economy, according to G. LAPPO, is that it and its elements ensure the conjugation of social and economic development, integral (district) and specialized (industry) systems.

In our opinion, spatial planning should be based on the integrated use of theories of spatial development, which will take into account the level of urbanization of the territory, imbalances in the development of central and peripheral territories, the possibility of integration of various regions, etc. At the same time, it should be noted that the varieties and scale of objects (settlements, industrial enterprises, economically developed and recreational zones, transport and engineering networks), types of economic activities form the structure and complexity of the economic space as a territory that has geographical, social, economic and environmental characteristics. It is important to note that the economic space is characterized by certain characteristics of education, possibilities for change and development under the influence of a combination of factors associated with targeted human activities.

Thus, in the context of globalization and the development of interregional, intercountry economic relations, the influence of the factor of territorial linkage of economic entities is significantly reduced. The active use in the modern economy of uniform rules of regulation in a territory without internal economic borders for the movement of labor, capital, goods and services contributes to the formation of a single economic space. A single economic space is characterized by close cooperation, a high level of integration, minimal barriers to economic activity, mobility and unhindered movement of resource, financial and commodity flows, economic security of the territory and other features. 
For example, the international agreement on the creation of the European Economic Space provided for the formation of a single internal market, through the free movement of goods, services and capital, the movement of people, and free trade rules. So, for example, in 2019, exports in Germany amounted to 1 trillion 327,6 billion euros, imports 1 trillion 104,1 billion euros, the main trading partners were France, the Netherlands, Great Britain, Italy, Poland, Austria, Switzerland and Belgium. In the Netherlands: exports - 655 billion euros, imports - 587 billion euros, main partners France, Germany, Great Britain, Italy, Poland, Austria, Switzerland, Spain, Sweden, Belgium, Norway and Ireland. In Italy: exports - 586 billion euros, imports - 515 billion euros, main partners: Germany, Great Britain, the Netherlands, France, Poland, Austria, Switzerland, Spain, Belgium. In Belgium: exports - 505 billion euros, imports - 460 billion euros, the main partners: Germany, Great Britain, the Netherlands, France, Poland, Italy, Spain, Luxembourg, Ireland.

The process of materialization of the economic space is urban planning, within the framework of which it is possible to organize the ratio of the structural components of the territorial space (city, region, country) through forecasting, design, zoning of the territory, including the allocation of industrial and residential zones. English architect-planner P. Abercrombie is the founder of the use of zoning as a new area of spatial planning, providing a comprehensive solution to the economic, engineering and planning problems of spatial development of territories. At his suggestion in 1922-1925g the Doncaster basin of London was divided into an industrial zone (any housing construction was prohibited) and a neutral zone (settlements and some harmless enterprises were allowed to be located).

The active development of urban planning involves the improvement of spatial planning methods that allow optimal use of the territory's resources, while ensuring comfortable living conditions, the effectiveness of productive forces, and the preservation of natural objects. In this regard, it is necessary to study the reference frame of the territory. This will make it possible to identify the specifics of the geographical division of labour, the points of localization of natural and economic resources, and the nature of transport interaction.

In ancient times, the supporting frame of the territory was a collection of sacred places, centers (energy nodes) and roads (energy lines). At present, ideas are being put forward in various scientific studies in which the system of megaliths, which acted as the organizational system of space, is considered the original frame of the territory.

For example, researchers (Lockyer, Somerville, Devoir) at the end of the 19th century drew attention to the phenomenon of the location of megaliths along clear lines and at a visible distance from one to another. In 1922, the idea of "ancient roads" arose, accordingly, the lines stretched many miles and coincided with prehistoric paths laid at a time when people found a road on the ground, traveling from one memorial structure to another in a straight line. Memorable places along these paths were stones, earthen embankments, ancient stone crosses at intersections, sacred trees and springs, ancient settlements, chapels, churches built on the sites of ancient sanctuaries. So, sometimes the remains of former roads that connected memorable places are still noticeable and, at the same time, coincide with the existing ones. 
English researcher A .Watkins, who collected topographic observations, local legends and customs in the book "Old Roads" (1925), concluded that the whole face of the British landscape with its roads, monuments, sacred places, settlements and traditions did not arise by chance, since it is based on the terrain marking of the Neolithic era. Modern layering refers to the ancient system of lines and centres that have developed on the basis of universal principles, and the study of which made it possible to create detailed maps of England's energy lines in a particular area. As an example of such a line, they call the energy axis through South England - from the Cornwall Peninsula extended far west to the edge of the east coast in Norfolk. This energy axis has the appearance of a chain of longstanding sacred places, starting from the rocky island of St. Michael with the monastery of the same name, through the world famous monuments of the Neolithic era and early Christianity (Glastonbury, Eubery, Mount St. Edmund) and others. These are "milestones," which are located along a powerful stream of geomagnetic energy, which is called the "line of St. Michael". Churches and chapels, which are especially important points of this line, are usually dedicated to St. Michael - the archangel, or St. George, as well as the Virgin Mary.

The doctrine of the supporting frame of the territory in official science is formed in the twentieth century, based on the ideas of W. CHRISTALLER, A.LOSCH, and other scientists who were searching for patterns of placement of objects of anthropogenic origin in space. These ideas were developed by G. LAPPO (1977), which under the supporting frame of the territory understood not only the totality of centres (nodes) and transport highways (economic lines), but emphasized that the supporting frame of the territory is a spatial subsystem in the territorial organization of society and economy; the result of the geographical division of labour; the totality of features of a particular territory; as well as, the display of the nature of sectoral and territorial structures and of the level of economic maturity. Thus, the basis of the supporting frame of the territory of the European Union is made up of the highways of European transport infrastructure: the Trans-European Transport Network, the Pan-European "corridors" and "zones," as well as the network of TINA (Transport Infrastructure Needs Assessment) of states associated with the EU (it is based on Pan-European corridors). The main functions of the European transport infrastructure are to ensure communication between metropolitan areas and the development of trade between geographically remote territories. Problems that need to be solved include the congestion of motorways, the modernization of railways, the low level of use of cabotage and transoceanic routes, the construction of alternative routes that reduce the burden on the environment.

The nodal elements of the supporting frame, which are formed in accordance with the needs of society and its productive forces, are divided into central places and specialized centers. Central places are nodes that perform central functions, are continuous and are expressed in a versatile service to the economy and population of the adjacent territories. Specialized centers are nodes with a sharp predominance of one or another industry. Nodes of the supporting frame are divided into the following categories: district organizing and district forming centers; inter-district interaction nodes; bridgeheads for the development of new resource areas; nodes of international economic contacts. Linear 
elements of the territory frame are transport highways that manifest themselves as economic axes that connect economically heterogeneous territories. So, the track is the place of ascent of links and the occurrence of nodes. The following types of economic lines are distinguished, the peculiarity of which is due to the natural and geographical situation: economic axes at the junction of mountainous and lowland areas; economic axes of the sea coast; economic axes along a large river; economic axes between two large centres; economic axis-beams. The combination of nodes and economic lines forms a kind of frame of territory, which predetermines one or another type of settlement in a particular area: radial-circular; grid of centres; linearly - nodal; seaside, etc.

The role of the frame is manifested due to the frame effect, the essence of which consists in combination of the effect of agglomeration, the effect of magistralization and the effect of displacement. These three components of the frame effect appear in the territory with a strongly marked central place of the highest rank, which is the canter of administrative formation and has connections with hierarchically lower central places of neighboring administrative formations. It is the frame effect that determines, in most cases, the peculiarities of the location of the centres of administrative regions, in particular their eccentric (peripheral) location.

The practical use of the concept of the supporting frame consists in a vision of the current problems of the territorial structure of macroregions, mesoregions and microregions. It provides a basis to distinguish points of economic growth, determine the dynamism and complexity of the territorial development processes, and identify imbalances in the development of urban and rural territories. The study of the supporting frame of the territory makes it possible to determine the nature of internal and external relations of economic regions, the level of concentration and dispersion of productive forces, priority economic specialization, the specifics of the location of nodes and lines within the territorial space, as well as to identify competitive advantages and integration opportunities of the regions. At the same time, attention should be paid to the nature of territorial-structural processes that occur in a particular region and can be monocentric (directed to one canter, focus, core or leaving one canter, focus, core) or polycentric (in the presence of several centres, focuses, cores, process sources).

In our opinion, the relevance of the polycentric model of spatial development for the European Union is due to the possibility of creating favorable conditions for the growth of both metropolitan areas and structurally weak regions, to reduce the level of differentiation between urban and rural areas and equalize environmental imbalances in the development of territories. In view of that the European Union is the specific territorial entity including split-level spatial systems (countries, regions, areas) studying a supporting frame will allow to reduce contradictions in the territorial organization of economy of member countries, using the principle of generalization.

Consequently, the use of spatial planning will ensure the balanced development of urban territories, regulate the growth of large centres through the formation of agglomerations of directed development, the priority development of the "second" city and "counterweight cities," and the activation of small and medium-sized cities outside the agglomeration. This will ensure the transformation of the location of cities, the allocation of 
agglomeration and the zone of influence of cities on the basis of central places and complementary areas, change of the pattern of settlement, in order to enable the polycentricity of the development of the territory. The formation and transformation of the nodal and linear elements of the supporting fram contribute to the progressive development of all levels of resettlement systems, ranging from local to state-wide, the formation of a special kind of super-agglomeration structures. The concomitant result is an increase in the efficiency of transport networks due to an increase in the speeds of various modes of transport (conversion of linear elements of the supporting frame) and polymagistralization (parallel following of a common route by several modes of transport). This makes it possible to lower the differences between urban and rural areas in terms of accessibility and quality of transport services.

The results of the study of the supporting frame of the territory are a platform for the development of strategic plans for territorial development, since they provide bases to distinguish the core (cores) of development, business centres, strategic transport routes and communications, settlement centres, places-"satellites" of business activity and settlement, chords of accessibility. The study can determine the limits of the pendulum effect, promising mergers of places of residence. Furthermore, it can change the purpose of the existing elements of development of urban and rural territories.

The result of the development of the supporting frame as the basis of the territorial organization of the life of society is a "frame effect," which is manifested in the combination of positive results of social and economic activities. This proves the existence of a fairly stable relationship between the level of social and economic development of the region and the spatial organization of supra-agglomeration structures and the supporting frame of resettlement.

In our opinion, the concept of the supporting frame of the territory can ensure a balance between social and economic development and the preservation of the natural environment, through the use of a binary model of the spatial combination of two frames: supporting and environmental. The main idea of the approach is the harmonious development of ecological and economic systems, as well as the adaptation and interpenetration of components of the supporting and ecological frames.

The ecological frame is a spatially organized network of natural and cultural landscapes, which vary depending on the nature of use and the level of involvement in the sphere of life, provided that the biodiversity of natural systems is preserved. A practical aspect of this approach is the need to design the ecological frame of the territory, which includes the development of proposals for the protection of nature, restoration, preservation and improvement of natural landscapes, historical and cultural monuments. The basis of these proposals should be the results of studies of the level of anthropogenic and technogenic load, maximum permissible standards for the use of natural resources (water bodies, land resources, air, etc.), the presence of pathogenic zones.

In order to justify effective management decisions regarding spatial development, it is proposed to zone the territory, which provides for its division into independent parts (zones) regarding to different geophysical planning, areas of development of territories or settlements depending on the availability of territorial resources (natural, economic, social), 
the type of use of the allocated zones and restrictions on their use, the nature of the problems. Zone should be considered as a space between any borders or a territory, a site characterized by certain features. In this case, zoning is considered from the point of view of distinguishing zones according to certain characteristics of a given territorial entity, which makes it possible to more accurately determine all the prerequisites for the possible specialization of economic activities and ensure environmental safety.

Zoning is one of the tools for the rational deployment of productive forces and it allows to solve social, economic and environmental problems of the region by dividing the territory into zones, taking into account the possibility of using its potential as a competitive advantage. The region is a holistic system - a space within a certain territory, which is characterized by natural-geographical, socio-demographic, political-administrative characteristics and is formed under the influence of various external and internal factors. In order to harmonize regional priorities and determinants of development, zoning is used as an effective tool of regional policy. The use of various types of zoning, including problematic, economic, functional, administrative-territorial and environmental, provides for identification of regions depending on the nature of problems, economic specialization, the availability of resources, etc.

Problematic zoning identifies problematic regions: depressed, crisis, backward. Depressed regions are characterized by the impossibility of resuming demographic, economic and other processes that ensure economic growth, in this territorial formation. An important characteristic of depressed regions is the loss of their abilities for economic growth, subject to positive trends in economic and social development in the previous period. Crisis regions are territories whose development is characterized by significant economic and social deformities due to the impact of natural disasters, political conflicts, and economic crises. Backward regions are territories with traditionally low living standards, low business activity and low scientific and technological potential.

Economic zoning is based on the allocation of economic areas that have developed historically or are being formed due to the process of developing productive forces and industrial relations, have a close relationship with natural resources and reflect the level of localization of economic activity. According to economic zoning, it is proposed to allocate regions (industrial, agricultural, recreational, etc.), in the territory of which a certain specialization of economic activities has been formed in accordance with the available natural and economic resources, which ensures full employment of the population. This approach is the basis for the formation of an optimal territorial organization of the economy and justifies priority economic activities for territorial entities.

The main goals of functional zoning are the determination of the assignments and uses of the territories of the region; preparation of a basis for the development of a regulatory legal act - land use and development rules, including urban planning zoning and the establishment of urban planning regulations for territorial zones; identification of territorial resources and optimal investment and construction strategy for the development of the region, based on effective urban planning use of the territory. The use of functional zoning makes it possible to create an optimal structure of spatial development of industrial and residential zones in accordance with the needs of the population and environmental 
protection standards, as well as to create conditions for the development of engineering and transport infrastructure. Functional zoning is the basis for general territorial planning, which involves the development, harmonization and approval of analytical, planning and project spatial planning documents (master plans, territorial programs, projects and cadastre), with the aim of effective organization and rational use of the territory. The rational organization of the territory ensures the comprehensive and effective development of urban and rural settlements, industrial and communal objects (zones), objects of other sectors of economic activity, recreation objects (zones), social and engineering transport infrastructure, the natural environment, historical and cultural heritage.

Administrative-territorial zoning involves the territorial division of the region into smaller administrative regions, taking into account economic, geographical, social, cultural and historical factors and traditions. So, in Europe, there are single-link (communities in Andorra, Liechtenstein), two-link (provinces and municipalities in the Netherlands), threelink (autonomous communities, provinces and municipalities in Spain) and four-link (regions, metropolitan cities, provinces and communes in Italy) systems of administrativeterritorial division. In accordance with the peculiarities of the administrative-territorial structure, a system of state authorities and local self-government is formed.

Depending on the administrative and territorial borders of the region, border and coastal territories are distinguished. The border territories are territories that are significantly influenced by the state border, which implies the possibility of integrating the border territories of different countries. In general, the development of foreign economic relations of the border regions compensates for their distance from the main economic centers of the country, thus increasing their competitiveness. Coastal territories are defined as limited long-range parts of land with inherent natural and anthropogenic properties and resources, which are characterized by length (area) as a special type of "spatial" resource, as well as, by geographical location and other economic, political and military qualities. The peculiarity of the location of the coastal territories determines the concentration of various types of marine economic activities, which actualizes the need to ensure the sustainable development of coastal zones.

Ecological zoning provides for the establishment of boundaries of territories, water areas, airspace, natural objects and resources in order to ensure their rational use and protection. The use of ecological zoning makes it possible to allocate buffer zones and specially protected natural areas in order to establish norms of anthropogenic load, restrictions on the use of territories and restore the balance of natural systems and objects. Buffer zones form state lands for multi-purpose use, which are located at the junction of the supporting and ecological frames and operate in a limited use mode. These zones are used to organize tourist trails, settlements adapted to nature, rational land ownership, and environmentally friendly industries. Especially protected natural territories are presented by the largest objects (reserves, wildlife areas) which form nuclei of an ecological frame, and buffer zones are the connecting elements (axes, corridors). The main function of specially protected natural areas is to transform the ecological frame, as well as to reduce the level of negative impacts of production activities, to create conditions for recreation of 
the population and the development of domestic tourism, and to preserve historical and cultural heritage.

The territorial organization of the regional public system, as well as the public systems of any other hierarchical level, depends on the presence and location within this system of zones that are active in relation to a person and his activities. SHEVCHUK (2003) notes that these zones act on a person in two ways: their influence can be positive (sacred) or negative (pathogenic). People have long known about such zones and called them "special places," which differed in functional use. In pathogenic places, houses were not built, and, on the contrary, in "sacred places" religious buildings arose and sacred activities were carried out. As we see, zones active in relation to man and his activities determine the features of the development of space, and act as determinants of the territorial organization of society. In view of this, it is understandable why the study of such zones within the framework of spatial planning has recently intensified. The location of pathogenic zones affects the results of various activities, since zones act as negative or positive factors. At the same time, the most important thing is that such places negatively or positively affect the state of human health.

Pathogenic zones are formed on the sites of former reservoirs, dried up rivers, in ravines, in the burial zone. In such places, phenomena were observed that science could not explain. So, people who were in such places could feel negative emotions (for example, fears, phobias), see non-existent things (in particular, hallucinations), more often have serious diseases (oncological, mental, etc.). An anomalous zone is a territorial formation where anomalous phenomena are observed for a fairly long time with a certain regularity, which are not recognized by official science. A number of studies of abnormal zones have been carried out in Germany, Switzerland, Belgium, France, Austria. As noted by MIZUN (1993), the network of biopathogenic zones was opened in 1937 and its negative impact on human health has been proven.

The work of scientists M. CURRY, E. HARTMANN, F. SCHTEGGENBURDER drew the attention of scientists and the public to the study of pathogenic zones. M. CURRY stated that biopathogenic bands are a grid formed by parallel lines and stretches across the Earth from southwest to northeast, and perpendicular from northwest to southeast.

HARTMANN (1986) summarized the author's many years of work in assessing the impact of geopathogenic zones on human health. The scientist SHEVCHUK (1997) presented the results of a study of pathogenic zones of various scientists of the twentieth century and substantiated the need to study the influence of biopathogenic zones on the state of individual and public health.

Observations of geopathogenic zones in different countries of the world revealed an increased accident rate of transport, a decrease in crop yields, a slowdown in the reproduction of various systems within the boundaries of these zones. Over the past 70 years, the study of the influence of geopathogenic zones on the functioning of anthropogenic objects has been especially intensified, since scientific research confirms the reality of such influence. Geopathogenic zones are local geophysical anomalies that negatively affect any organisms: humans, animals, plants. However, there are a number of questions that need to be answered, for example, what is this impact in duration? Could 
a dosed short-term stay in these areas be positive? What underlies the genesis of geopathogenic zones?

One of the hypotheses of the genesis of geopathogenic zones uses the generation of "earth rays" - special radiation that occurs at the intersection of underground water flows and geological faults, or their general action. In our opinion, individual geopathogenic zones can be formed in this way, but, obviously, there may be other factors of the emergence of geopathogenic zones, for example, pathogenicity in the zone of burials and prisons has long been noted. BRUNOV (2005) suggested that the geopathogenic zone arose from the manifestation of heterogeneities in the structure of the earth's crust. According to him this zone causes an abnormal energy information field that negatively affects the energy of biosystems and objects of lifeless nature. So, obviously, the significance of the geophysical factor in the genesis of geopathogenic zones is recognized. Another confirmation of the above is the hypothesis that geopathogenic zones consist of gravitational-electromagnetic radiation of the Earth, which keeps the Earth's surface in a solid state. As a result of living organisms staying within their borders, the thin, and then the physical shell is destroyed. Seven days in such zones are sufficient for biological cells to change their polarization and structure.

Scientists suggest that even non-biological objects respond to the influence of geopathogenic zones. So, German scientists have revealed that even capital buildings in such zones function 30 years less, and electronic technology, which is within the range of influence of geopathogenic zones, wears out prematurely. The relevance of the study of problems of geopathogenic zones is confirmed by discussions at numerous seminars and conferences. So, for example, in 1997 in Cyprus, an international seminar on problems of geopathogenic zones was held in Larnatia, in which scientists from Austria, England, Brazil, Cyprus, Canada, Sweden, the CIS took part. Modern geophysical studies confirm that there are certain areas on the surface of the Earth where the physical parameters of the environment differ from those recorded in neighboring areas. Such anomalies were identified using the most modern equipment underground and even during measurements from the aircraft.

It should be noted that anthropogenic objects such as power lines, underground communications and other factors can increase the influence of natural geopathogenic zones, or create anthropogenic geopathogenic zones, which has already been proved in the framework of official scientific research. So we can conclude that all areas on Earth can be divided into three species, in terms of the influence on living organisms: positive (sacred), negative (pathogenic), neutral. It is very important to study not only the location of these three types of areas in the region, but their location relative to such objects as transport highways, residential buildings, social, cultural and consumer services institutions, etc. According to the genesis, every of three types of areas can be divided into another three types: natural origin (voids, water flows, mineral reserves); anthropogenic origin (anthropogenic structures or other results of anthropogenic activity - underground structures, metro, mines, pipelines, cable networks, landfills, burials, etc.); social origin related to human behaviour (places of ethnic, religious and social conflict). 
The obvious fact is that in ancient times people, not only knew how to determine the influence of certain sections of the Earth on humans, knew the peculiarities of structuring the space where such sections occupied a specific position, but also used this information in their activities (cult, economic, recreational). In such areas of the Earth, the former inhabitants left peculiar marks that could be both very small and gigantic in the modern sense of the word. The so-called "small marks" (individual stones, a pile of stone, bowls of stone, etc.) cannot always be recognized. Later signs (crosses, chapels, figures) can easier be seen. The big signs left by the ancestors are megaliths that normally can be observed. Such megaliths include menhirs, cultivated stones, several meters long, which are vertically dug into the ground; cromlechs are circles of stone blocks; dolmens, longstanding megalithic structures in the form of a large, mainly symmetrical, stone box or chamber of four standing and perpendicular plates, which are covered with a flat plate, which can have a length of up to ten meters and weight - up to several tens of tons. The purpose and method of building such structures is unknown, although these structures are common in most countries of the world. The age of the oldest Menghirs dates from the eighth millennium BC, most of them belong to different eras. It is also interesting that the closer the megaliths are to the sea, the larger they are, the farther away from the sea, the smaller these structures are. Along the Black Sea coast there are several megaliths, the most famous of which are dolmens. So, on the territory of the Crimea Peninsula is the Pallas megalith, a group of dolmen 2-3 km from Eski-kermen and from Mangup, as well as 20 megaliths and 40 dolmens on Cape Ai-Todor.

On Easter Island (Rapanui) there are more than 300 megalithic platforms (ahu) and about 1000 stone statues (moai), which were built in the 13th century by the Polynesian civilization of Rapanui. American anthropologists have studied the location of ahu platforms on which stone statues "sit." During the study, scientists compiled a map of the island, which indicated the location of natural wealth, including fresh water sources. It turned out that near all megalithic structures there are springs. In other parts of the island, there were no sources of freshwater.

Thus, many researchers have recorded that megalith is located in special places, which in geological terms are faults and shifts of earth's rocks, which are usually accompanied by the presence of minerals, groundwater flows, and the manifestation of terrestrial magnetism. It was revealed that the placement of megalith is not chaotic, arbitrary or random, but strictly landscaped. This assumption proves the presence of the "energy line" discovered in Southern England by P. Broadhurst and H. Miller, which stretches 300 miles along the south coast in the form of the greatest monuments of Southern England, which represents the movement of this mysterious flow of natural energy. A detailed study of the "energy line" made it possible to build a hypothesis about the content of ancient sacred places as a system aimed at capturing, amplifying and transforming thin energies, of both, the Earth itself, and of its inhabitants, and those energies that come from outer space.

The practical use of zoning of territories in spatial planning consists in the development of master plans, regional development strategies, legal and environmental regulations for the use of land and natural objects, to optimize the layout of productive forces. The main goal of zoning is to ensure a balanced development of the territories of the region, which 
are differentiated depending on the efficiency of the use of natural and economic potentials, the level of development and anthropogenic load. Zoning enhances spatial planning for the creation of new zones or the reprofiling of existing zones by changing the specialization of economic activities, which ensures the optimal territorial structure.

\title{
Completion in the next issue of the magazine
}

\author{
Literature \\ 1. Augère-Granier M.-L. EU rural development policy / M.-L. Augère-Granier URL: \\ http://www.europarl.europa.eu/RegData/etudes/BRIE/2015/568340/EPRS_BRI(2015)568340_EN.p \\ df. \\ 2. BARANSKY, P. (1980): Selected Works: The Formation of Soviet Economic Geography, \\ $M$.: Thought. \\ 3. Bilan, Y., Mishchuk, H., Samoliuk, N., \& Grishnova, O. (2019). ICT and Economic Growth: \\ Links and Possibilities of Engaging. Intellectual Economics, 13(1), 93-104. Doi: \\ https://doi.org/10.13165/lE-19-13-1-07 \\ 4. BRUNOV, V. (2005): Influence of geo- and technopathogenic zones on various aspects \\ of life, Moscow: Amrita-Rus \\ 5. CHAUNCY, D. HARRIS AND E. ULLMAN (1945): The Nature of Cities, The Annals of \\ the American Academy of Political and Social Science 242, 7-17. \\ 6. CHRISTALLER, W. (1967): Central Places in Southern Germany, NY: Englewood Cliffs. \\ 7. Corona crisis in Europe will be worse than the world one. We'll have to spend trillions of \\ euros, but the problem is not money. URL:: https://www.bbc.com/russian/features-52345671. \\ 8. EU economy: a new test of strength. URL:: https://expert.ru/2020/06/2/ekonomika- \\ evrosoyuza-novoe-ispyitanie-na-prochnost/ \\ 9. Eurostat // URL: \\ https://appsso.eurostat.ec.europa.eu/nui/show.do?dataset=une_rt_a\&lang=en. \\ 10. Hrishnova, O. A. (2006). Liudskyj rozvytok [Human Development]. Kyiv: KNEU, 2006, \\ $308 \mathrm{p}$. \\ 11. HARTMANN, E. (1986): Disease as a problem of location, M.: publishing house Nauka. \\ 12. ISARD, W. (1956): Location and space economy. Cambridge, Mass.: MIT. \\ 13. Kalenyuk, I., Tsymbal, L., Grishnova, O., \& Djakona, A. (2020). Intellectual component of \\ global leadership. Management theory and studies for rural business and infrastructure \\ development= Vadybos mokslas ir studijos-kaimo verslų ir jų infrastruktūros plètrai: mokslo darbai, \\ 2020, vol. 42, no. 4, p. 476-485. \\ 14. KOLOSOVSKY, N. (2006): Selected Works, Smolensk: Oikumena. \\ 15. LAPPO G. (1977: Development of urban agglomerations in the USSR, M.: Science. \\ 16. LAUNHARDT, W. (1882): Die Bestimmung des zweckmässigsten Standortes einer \\ gewerblichen Anlage, Zeitschrift des Vereines deutscher Ingenieure 26 (Mar), 106-115. \\ 17. LOSCH, A. (1945): The Economics of Location. 2nd edn. / trans W.H. Woglom with the \\ assistance of W.F. Stolpen (New Haven, CT, 1954). First published in 1940. \\ 18. MIZUN, Y. (1993): Biopathogenic zones - the threat of disease. - M.: SPC «Ecology and \\ Health». \\ 19. MIZUN, Y. (1988): Processes in the geosphere, M .: Knowledge \\ 20. MOROZOVA, N. (2015): Rural Development: Foreign Experience, Socio-economic \\ phenomena and processes 6, 63-69. \\ 21. PERROUX, F. (1950): Economic space: theory and applications, Quarterly Journal of \\ Economics 64, 79-82. \\ 22. PONSARD, C. (1958): Histoire des theories économiques spatiales. Paris: Colin
}


23. ROSHER, W. (1854): System of the National Economy". V. 1. "Beginnings of the National Economy"

24. SCHTEGGENBURDER, F. (1953): Reizstreifen und Netsysteme, «Z.Radiasthesie» 5,

25. SHEVCHUK, L. (2003): Medico-social aspects of the use of labor potential: regional analysis and forecast, Lviv: IRD NAS of Ukraine.

26. SHEVCHUK, L. (1997): Fundamentals of medical geography, Lviv: Ivan Franko Lviv National University.

27. THÜNEN, J. (1826): The Isolated State'. An English edition of Der isolierte Staat / by Johann Heinrich Von Thunen (1966).

WEBER, A. (1909): Über den Standort der Industrien Berlin.

Ірина Бережна, д.е.н., професор,

Fondo Bilateral para el Desarrollo en Transición Chile - Unión Europea, Сантьяго, Чилі

Олена Грішнова, д.е.н., професор,

Київський національний університет імені Тараса Шевченка, Україна

Катерина Міхурінська, д.е.н., профессор,

Fondo Bilateral para el Desarrollo en Transición Chile - Unión Europea, Сантьяго, Чилі

Артем Бережной, д.е.н., менеджер ланцюга постачання, Hunland Impex BV, Нідерланди

\section{ПРОСТОРОВЕ ПЛАНУВАННЯ ЯК ОСНОВА ПРОСТОРОВОГО РОЗВИТКУ, КОНСОЛІДАЦІЯ ЗУСІЛЬ ТА СОЛІДАРНОСТІ ОБ'ЄДНАНОЇ ЄВРОПИ. ЧАСТИНА 1.}

Враховуючи, що метою просторового розвитку Європейського Союзу $\epsilon$ забезпечення сталого розвитку європейських регіонів, зміцнення демократичних структур на регіональному та муніципальному рівнях та підвищення конкурентоспроможності, корисність просторового планування є виправданою. Це дозволить удосконалити розміщення продуктивних сил, схеми розселення, виділити території найважливіших природних об'єктів з урахуванням спеціалізації економіки, рівня розвитку, характеру використання природних ресурсів та економічного потенціалу тощо. Запропоновано підхід до просторового планування, який передбачає визначення особливостей опорного каркаса, зонування території з урахуванням соціальних, економічних та екологічних особливостей, оптимізацію територіальної структури. Це створить умови для подолання структурних змін у просторовому розвитку регіону, пов язаних із необхідністю регулювання процесів землекористування, інтеграцією різних регіонів (галузей, підприємств), розвитком мономіст та сільських територій, оптимізації транспортних коридорів, стабілізації екологічного фрону. Приділено увагу гармонійному взаємному розвитку еколого-кономічних систем, що забезпечується проектуванням архітектури несучих та екологічних каркасів. При цьому результати досліджень рівня антропогенного та техногенного навантаження, гранично допустимих норм використання природних ресурсів (водних об'єктів, земельних ресурсів, повітря тощо), а також наявності патогенних зон, слід брати до уваги. Реалізація запропонованого підходу потребує консолідації зусиль територіальних громад на різних рівнях на засадах співробітниитва, інтеграції та об'єднання, що враховує загальні тендениії розвитку та специфрічні особливості територій. Головним результатом стане зміцнення співдружності, посилення солідарності країнучасниць у досягненні стратегічних орієнтирів збалансованого розвитку Європейського Союзу та ефрективної протидії сучасним викликам.

Ключові слова: просторовий розвиток; Європейський Союз;сталий розвиток, територіальне планування, оптимізація територіальної структури. 